\title{
10. 呼吸器感染症の最近の知見
}

\author{
杏林大学医学部第一内科 後藤 元
}

呼吸器感染症の領域でも耐性菌は大きな問題 となっている. 今回の講演では, 肺炎球菌, イ ンフルエンザ菌をはじめとする呼吸器感染症の 主要な原因菌について薬剂耐性化状況を中心と して，その現状とこれに対する抗菌薬の選択に ついて述べる。薬片耐性化については, 1981 年以来 4 半世紀に亘り調査を続けてきた呼吸器 感染症分離菌感受性調查研究会の成績を主とし て紹介したい。

肺炎球菌については, その特効薬は, これま で一貫してペニシリンであったが, 近年, 急速 にペニシリンに対する耐性化が進行している. 1990 年には分離された肺炎球菌の $90 \%$ 近くが, ペニシリンに高い感受性を示していた. しかし， 近年明らかに感受性は低下し, 中等度耐性菌 (PISP), および耐性菌 (PRSP) が増加している. こうした肺炎球菌のペニシリン耐性は, 海外で も問題とはなっているが, その深刻さはわが国
で際だっている. マクロライドについても 1990 年には，60\%を越える菌株がエリスロマイシン に高い感受性を示していたが, 2001 年には感受 性株は, $10 \%$ にまで減少している。 マクロライ ド耐性肺炎球菌も，わが国は特別に目立つ国の ひとつになっている.

インフルエンザ菌の耐性発現機序には, $\beta$-ラク タマーゼ産生によるもの (BLPAR) とペニシリ ン結合蛋白の変異によるもの (BLNAR) とがあ る. 現在わが国ではいずれによるものも分離さ れているが, 90 年代後半からは, 特に後者の増 加が目立ち, 最近では分離株の $30 \%$ 以上を占め るに至っている.

以上のような耐性菌は, 抗菌薬の使用に伴い 必然的に発現してきたものであり, 抗菌薬の使 用はすなわち耐性菌の発現を導くという宿命を 背負っている。 こうした意味で, 日常臨床にお ける抗菌薬の適正な使用が強く望まれる.

\section{1．潰瘍性大腸炎の病態と治療}

\section{慶應義塾大学内科 日比 紀文}

近年わが国における炎症性腸疾患の患者数は 増加の一途をたどっているが, その根本的原因 は未だ不明である．遺伝的因子は欧米において 指摘されている疾患関連遺伝子のpoint mutation を中心とした異常についてはわが国では認めら れておらず，遺伝的背景の相違がみられる。一 方, 戦後の食生活の変化, とりわけ動物性蛋白 や脂肪の摂取量増加は, 炎症性腸疾患患者数の 増加とその時期がほぼ一致しており，食事や契 煙などの環境因子や腸内細菌叢の動態が病因 ·
病態に深く係わっていると考えられる.

最近の国内外における研究成果により潰瘍性 大腸炎とクローン病の病態は大きく異なってい ることが明らかとなってきた. 臨床的に潰瘍性 大腸炎と診断されている症例の中には, 種々の ウイルスや細菌感染症が含まれている可能性も ある. しかし, 大腸粘膜が特異的に傷害され, 血清中に自己抗体が出現し, 腸管外合併症を伴 うことなどより, 全身の免疫異常を伴う臓器特 異的自己免疫疾患とする考え方も可能である. 